Transnational Business Governance Interactions Project Working Paper No. 37

November 2018

\title{
Interactive Strategies for Advancing Marginalized Actors in Transnational Governance Contests: Labour and the Making of ISO 26000
}

\section{Stepan Wood}

University of British Columbia

This paper is available free of charge from www.tgiforum.org

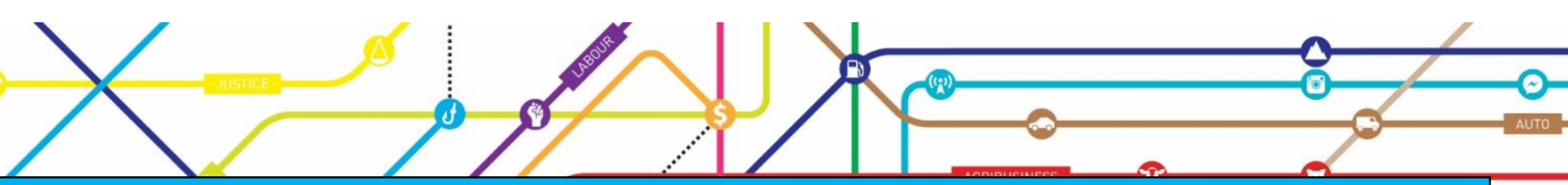

The TBGI Project: Transnational initiatives to regulate business activities interact increasingly with each other and with official regulation, generating complex governance ensembles. Heterogeneous actors and

institutions interact at multiple levels and in various ways, from mimicry and cooperation to competition and conflict. The TBGI Project investigates the forms, drivers, mechanisms, dynamics, outputs and impacts of transnational business governance interactions (TBGI) from diverse theoretical and methodological perspectives. It is led by Stepan Wood, Professor and Canada Research Chair in Law, Society and Sustainability at the Peter A. Allard School of Law, University of British Columbia.

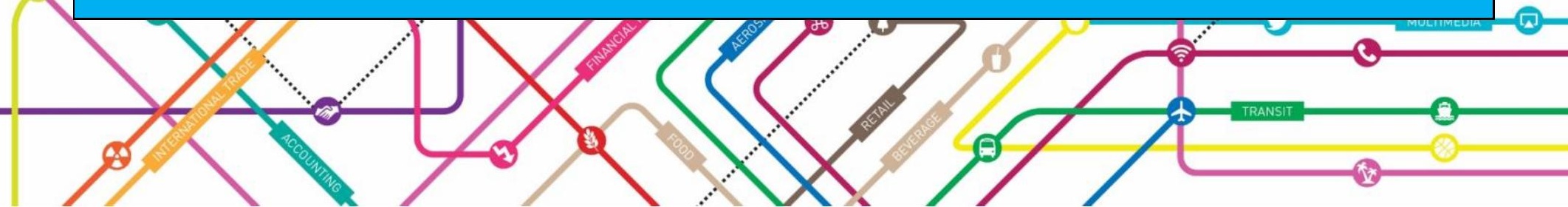




\title{
Interactive Strategies for Advancing Marginalized Actors in Transnational Governance Contests: Labour and the Making of ISO 26000
}

\author{
Stepan Wood*
}

\section{Abstract}

This chapter explores the role of organized labour in drafting the ISO 26000 guidance standard on social responsibility (SR) as a case study of the circumstances in which weaker actors can take advantage of transnational business governance interactions (TBGIs) to achieve regulatory outcomes that advance their interests. Organized labour initially opposed the development of an ISO standard on SR and was vastly outnumbered when it joined this project in a defensive posture. Yet it achieved remarkably wide and strong protection for workers in ISO 26000 compared to other leading SR initiatives. Integrating theories of legitimation and regulatory enrolment, I theorize regulator-audience relationships and the circumstances in which one can expect a regulator to acquiesce to a particular audience's legitimation demands. I argue that organized labour was unlikely on its own to secure ISO's acquiescence to its legitimation demands, but it succeeded by both proactively leveraging and passively coasting upon the delicate relationship between a transnational regulator that lacked legitimacy and other regulatory resources - ISO-and another actor - the International Labour Organization (ILO) - that could supply those resources. I theorize a triadic strategy in which a regulatory underdog exploits legitimation differentials between a legitimacy-poor regulator and a legitimacy-rich booster to advance its interests, and the booster is doubly enrolled by the regulator (to enhance the regulator's legitimacy) and the underdog (to boost the underdog's effectiveness).

\section{Keywords}

ISO 26000, International Organization for Standardization, International Labour Organization, organized labour, legitimation, enrolment

\footnotetext{
* Professor and Canada Research Chair in Law, Society \& Sustainability, Peter A Allard School of Law, University of British Columbia. A revised version of this paper is forthcoming in Stepan Wood et al., eds. Transnational Business Governance Interactions: Advancing Marginalized Actors and Enhancing Regulatory Quality. Cheltenham, UK: Edward Elgar.
} 


\section{Introduction}

In this chapter I explore the drafting of the International Organization for Standardization's ISO 26000 guidance standard on social responsibility (ISO 2010b) as a case study of the circumstances in which weaker actors can take advantage of transnational business governance interactions (TBGIs) (Eberlein et al. 2014; Wood et al. 2015) to achieve regulatory outcomes that advance their interests. I argue that organized labour achieved results in ISO 26000 that belied its structural disadvantage and that this outcome was due to its exploitation of interactive dynamics between ISO and the International Labour Organization (ILO). The chapter proceeds in four parts. Part 1 presents a theoretical framework centred on concepts of legitimation and regulatory enrolment. Part 2 presents the case study in three parts: an introduction to ISO and the ILO, a description of organized labour's structural disadvantage in the making of ISO 26000, and an account of its success in protecting workers' rights in the final product. Part 3 argues that organized labour's mobilization of interactions between ISO and the ILO played a significant role in this success. Part 4 examines the implications of this case for theories of legitimation and proposes a triadic strategy in which an underdog takes advantage of interactions between a regulator and a booster to advance its interests in transnational governance and enhance regulatory standards.

\section{Legitimation Politics and Regulatory Enrolment}

In this Part I theorize TBGIs in terms of two interactive processes: legitimation and enrolment. Legitimation is the process by which an actor claims the authority to perform one or more components of a regulatory governance process and relevant audiences recognize this claim as valid. Enrolment is the process by which an actor accepts an assigned role in a network and makes its resources available for mobilization by other actors in the network (Latour 1984). The two strategies are distinct but interrelated: as I will argue below, legitimation necessarily implies enrolment but enrolment does not necessarily imply legitimation.

Legitimation is essential to regulation (Weber 1978, 953-54). It implies that audiences accept regulators' authority claims and modify their thinking and action accordingly (Black 2008, 148). The study of legitimation is the study of how would-be regulators seek or maintain authority, how other actors accept, contest or otherwise respond to such efforts, and how legitimacy is thereby conferred or withdrawn. Legitimacy, on this view, is an empirical phenomenon to be observed and interpreted. Normative and empirical questions are thoroughly intertwined in the study of legitimation, however. Legitimacy as an empirical phenomenon is constituted by normative claims and perceptions about what is desirable, proper or appropriate. Mark Suchman $(1995,574)$ famously defines legitimacy as 'a generalized perception or assumption that the actions of an entity are desirable, proper, or appropriate within some socially constructed system of norms, values, beliefs, and definitions'. Normative theories of legitimacy thus inform the social practice of legitimation. Conversely, the study of how legitimacy is constructed and contested in practice, with what effects and for whom, can and should inform normative evaluations of and prescriptions for the legitimacy of transnational governance (Black 2008).

For purposes of this chapter I theorize legitimation in terms of four propositions:

1. Regulators who claim legitimacy and the audiences of these claims are in a relationship of mutual autonomy and dependence;

2. In this relationship, regulators seek to secure legitimacy by creating, managing and manipulating audience perceptions and enrolling actors into desired regulatory roles; 
3. It is, however, acceptance by audiences, often made up of multiple legitimacy communities, that ultimately confers legitimacy and secures enrolment; and

4. Legitimacy is shifting, variable and constantly renegotiated as regulators face multiple and conflicting legitimation demands.

These propositions emphasize strategic, actor-centred dimensions of legitimation. Other dimensions are also important, including the institutional environments and discursive structures that shape strategic interaction (ibid.). To make the scope of inquiry manageable, I bracket those dimensions here and focus on strategic interaction amongst regulators and audiences.

My first proposition is that regulators and regulated are in a relationship of mutual, albeit often asymmetrical, autonomy and dependence. The regulated have some ability to influence their own conditions and the regulator's activities (Giddens 1982, 197-99). Regulators depend on the regulated for legitimacy. 'Legitimacy claims,' as Black $(2008,149)$ explains, 'are thus made both on and by regulators, and both regulators and legitimacy communities construct and contest the legitimacy of regulators, and indeed of one another'.

Second, would-be regulators act strategically to build their legitimacy. Mark Suchman (1995) identifies three kinds of legitimation strategies. Informing strategies seek to identify audiences that are predisposed to accept a regulator's authority, and alert them to the regulator's activities. Converting strategies seek to cause undecided or opposed audience members to change their evaluations and accept the regulator's authority. Finally, conforming strategies change the regulator's structures, processes or outputs to conform to audience members' expectations. All legitimation strategies 'seek to justify the exercise of power by claiming to set certain constraints upon its exercise' (Szablowski 2007, 18). For legitimacy to endure, audiences must believe that these constraints are generally observed in practice (ibid., 19). But legitimacy can be resilient to shocks: audiences forgive some transgressions (Black 2008, 145). On the other hand, legitimation strategies are unlikely to succeed or endure if they are exposed as superficial, manipulative or cynical (Gulbrandsen 2005, 2010; Fransen 2012).

Strategic legitimation efforts are aimed at enrolling actors into desired roles, including as rule takers, monitors, enforcers, adjudicators, trainers, even rule makers. These regulatory roles are often performed by multiple actors who must be recruited to take them on. Regulators often also seek to enrol actors into a range of roles outside the formal regulatory scheme, such as promoters, supporters, beneficiaries and other audiences to whom the regulator desires to project its authority and from whom it seeks legitimacy (Szablowski 2007, 14-15). Enrolment enables a regulator to mobilize the enrolled actor's symbolic and material resources in support of the regulator's goals (Verbruggen and Havinga, this volume). Such resources can include organizational capacity, convening power, communication networks, personnel, money, technology, information, expertise, reputation and legitimacy.

This brings me to my third proposition. Legitimacy is gained or lost depending on target audiences' responses to regulators' assertions of authority (Quack 2016, 363). Legitimacy is an endowment (Black 2009). It resembles a resource insofar as regulators seek to extract it from audiences and exploit it once gained. But unlike a resource, it is bestowed or withdrawn by others: a regulator does not have conclusive control over it (ibid.). Audiences can accept (with or without qualification), reject, or ignore regulators' authority claims. Audiences can include targets, beneficiaries, other regulators, constituents within the regulator itself, and other legitimacy communities. 
By accepting a regulator's assertion of authority, an audience member accepts the role assigned to it by the regulator. In other words, enrolment is a necessary outcome of a successful legitimation process. Legitimation succeeds to the extent that the audience is enrolled into the role desired by the regulator, whether as rule maker, target, compliance verifier or otherwise. The obverse is not true, however: enrolment does not necessarily entail legitimation. Legitimacy is just one resource that can be mobilized via enrolment; others include financial resources, technology, knowledge and expertise. An actor can accept an assigned role without conferring legitimacy upon the enrolling actor. Indeed, an actor can be enrolled in spite of itself, by threats or coercion (Callon 1984; Fox 2000). Hence legitimation implies enrolment, but enrolment does not imply legitimation.

To succeed, regulators' legitimation strategies must appeal to legitimating ideas prevalent among target audiences (Szablowski 2007, 19). Suchman (1995) distinguishes amongst pragmatic, moral and cognitive legitimacy. Pragmatic legitimacy exists where audiences accept a regulator's authority out of self-interest. Moral legitimacy exists where audience members accept the authority because it appears right and proper based on their ideas of justice or fairness. Cognitive legitimacy exists where audience members accept the authority unthinkingly due to habit, culture or identity. Different varieties of legitimacy appeal to different legitimating ideas and legitimacy communities; if one fails, another cannot necessarily take its place (Black 2008, 152).

Audiences' abilities to affect a regulator's legitimacy also vary. Well organized, attentive and resourceful audiences are likely to have more influence than disorganized, heterogeneous and under-resourced ones (Szablowski 2007, 20). A regulator often has a core audience whose acceptance or rejection is crucial, and non-core audiences whose responses are less important or dispensable (Cashore, Auld, and Newsom 2004, 240).

The fourth proposition follows from the previous two. Legitimacy is shifting, variable and constantly renegotiated as regulators face multiple and conflicting legitimation demands (Cotterrell 2016, 254). This is especially true in transnational settings, where regulators cannot rely on the legitimating power of the nation-state and democratic accountability (Bernstein and Cashore 2007, 351). Legitimacy in this context is 'continuously open to challenge and never assured' (Webb 2015, 472). It is 'something fluid that must be repeatedly created, recreated, and conquered' through 'a continuous and intensive negotiation' (Tamm Hallström and Boström 2010, 160). Regulators often face a dilemma: 'what they need to do to be accepted by one part of their environment, within and outside the regulatory regime, is contrary to how they need to respond to another part' (Black 2008, 153). Little is known about which legitimation demands regulators are likely to respond to, which they will ignore and how their responses are affected by their institutional environments and their relationships with other regulators (ibid., 154-155). Julia Black hypothesizes that regulators are less likely to acquiesce to audiences' legitimation demands, even if the legitimacy gains for that regulator within that particular legitimacy community may be high, where:

(i) the regulator perceives itself to have a low dependency or interconnectedness on that legitimacy community for the performance of its regulatory function; (ii) where the content of the claims, and the discourse in which they are articulated, is not congruent or consistent with the regulator's, or is only so to a moderate degree; (iii) where acquiescence with the claims would pose moderate to severe constraints on the ability of the regulator to determine its own structures, goals and activities; (iv) where the legitimacy community has little means, directly or indirectly, to coerce the regulator to respond; (v) where the claims being advanced are not widely diffused among others within or outside the regulatory regime; and (vi) the consequences of acquiescing are uncertain (Ibid., 156). 
She predicts that a regulator is more likely to acquiesce to legitimation demands where the opposite is true for some or all of these factors.

The case of organized labour's role in the development of ISO 26000 provides a useful context in which to consider Black's hypotheses and investigate the circumstances in which weaker actors can harness the interactive dynamics of legitimation and enrolment to prevail in transnational governance contests.

\section{Labour, the ILO and the Making of ISO 26000}

Organized labour's role in the development of ISO 26000 is a suitable case study because ISO is an influential global standard setter, ISO 26000 is among the leading global articulations of social responsibility, its drafting involved a high degree of TBGIs, and organized labour secured a remarkably favourable result compared to other contemporary social responsibility initiatives.

\subsection{ISO, the ILO and Social Responsibility}

ISO is the leading source of voluntary standards for global business. It began operations in 1947. By 2017 it had 163 national member bodies and almost 22,000 international standards in print (ISO 1997, 2018). More than 1.6 million organizations worldwide have management systems that are certified against ISO management system standards (ISO 2017). Business interests from the advanced industrialized democracies dominate ISO's leadership and its standards development activities (Murphy and Yates 2009; Wood 2012b).

The International Labour Organization (ILO) celebrated its centenary in 2019. Its mission is to advance social harmony via a tripartite dialogue amongst workers, employers and states. Aside from the International Maritime Organization, it is the only global organization with this tripartite structure. It is a specialized agency of the United Nations and has 187 member states. Unlike ISO, it creates binding international law in the form of conventions that are presented for ratification by member states. It is the authoritative source of international labour standards (ILSs), which take the form of legally binding conventions and non-binding recommendations.

The ILO was active in the field of corporate social responsibility (CSR) decades before the term was coined. ISO's move into this field began in 1993, when it launched the ISO 14000 family of environmental management standards. Building on the success of these standards, it began to consider developing broader CSR standards. Consumer representatives in ISO believed that an ISO standard could bring some consistency and reliability to the myriad claims of social responsibility advanced by companies around the world. A working group of ISO's consumer policy committee (COPOLCO) concluded in 2002 that ISO was well positioned to develop CSR management system standards. On its recommendation, ISO established a high-level Ad Hoc Group on Corporate Social Responsibility (AHGCSR) to advise it on whether to develop ISO CSR standards. The AHGCSR submitted its final report in April 2004, recommending that ISO should develop SR standards only if it recognized, among other things, that it had no authority to set social expectations that are properly defined by representative political institutions; that private voluntary initiatives differ from, and may not reflect the universal principles contained in, authoritative intergovernmental instruments; and that the ILO had a 'unique mandate as the organization that defines, on a tripartite basis, international norms with respect to a broad range of social issues' (ISO 2004b, 1).

ISO received mixed feedback from its audiences about the prospect of ISO CSR standards (Tamm Hallström and Boström 2010, 30-35). Business actors were opposed because CSR was too 
diverse and contested to be standardized, and they did not want to encourage the growth of an SR consulting and certification industry. Government representatives were ambivalent, recognizing the potential of voluntary standards to support public policy goals but critical of ISO's democratic deficit. Developing country governments also feared that ISO standards could become trade barriers. Some intergovernmental organizations favoured voluntary non-governmental standards; others saw them as unwelcome interlopers. Public interest NGOs ranged from ambivalent to hostile. WWF International participated in the AHGCSR but then left over concerns about stakeholder imbalance and inadequate attention to environmental protection. Voluntary standard-setters saw ISO as a potential competitor but also a potential force magnifier for their standards. Labour was hostile because it saw the ILO as the appropriate forum to pronounce labour standards, believed ISO to be captured by business, and considered international framework agreements between trade union federations and transnational companies a more promising tool. The ILO was ambivalent, seeing ISO as a politically unrepresentative and inappropriate forum for grappling with social justice issues, but also as a possible avenue toward greater uptake of international labour standards.

ISO's Technical Management Board (TMB) decided to go ahead with the development of a guidance standard. The Brazilian and Swedish ISO member bodies agreed to co-lead the work. The TMB invited each ISO member body to nominate up to six experts, one in each of six stakeholder categories: industry, government, labour, consumers, NGOs and others (ISO 2004a). The ISO Working Group on Social Responsibility (WGSR) met eight times between March 2005 and May 2010. It grew from 225 experts representing 43 national standards bodies and 24 international liaison organizations at its first meeting to 450 experts from 99 national standards bodies and 42 international organizations when it finished its work in 2010. ISO 26000: Guidance on Social Responsibility was published in 2010 (ISO 2010b). All of the records of the WGSR are publicly available on the Internet, opening a rare window into non-state standardization processes. ${ }^{1}$ This archive of almost 3000 documents was the main source for my research, along with participant observation as a member of Canada's national mirror committee ${ }^{2}$ and an observer at two WGSR meetings.

With this background in mind, I turn to the role of organized labour in the negotiations and the question of whether it was able to harness TBGIs to advance workers' interests.

\subsection{Labour's Disadvantage in the ISO 26000 process}

No labour representatives took part in the COPOLCO working group that provided the initial impetus for ISO's move into SR. The working group's report was 'written from a decidedly consumer perspective' (ISO 2002, ii). Labour was in turn vastly outnumbered on the AHGCSR. Nine (45\%) of the 20 AHGCSR members, including the chair, were from industry. Two represented standards development bodies, one was a management consultant and one was an academic-all four (20\%) falling into the Support, Service, Research and Others (SSRO) category later defined by the WGSR. Three members (15\%) of the AHGCSR were from environmental or CSR-related NGOs, and two (10\%) were from government and intergovernmental organizations. The labour and consumer categories had only one member each ( $5 \%$ of the total). To be fair, one of the governmental representatives was an ILO official, but even if we count him as representing labour (which would not be entirely fair as the ILO has a tripartite constituency), labour was still outnumbered ten to one.

Labour was similarly outnumbered in the WGSR. It was the smallest stakeholder category throughout the drafting of ISO 26000, starting at around 7\% of WGSR membership and ending at 
around $10 \%$. Although its size increased both absolutely and as a proportion of the WGSR membership, it never caught up with the second-smallest category, consumers. Moreover, the gap between these two categories and the others increased over time. Industry had the most members throughout, but its rate of growth slowed as time went on. The SSRO category started out as the second-largest but dropped to third over time. A large proportion of this category was made up of consultants and standards body staff, whose backgrounds and interests are broadly aligned with those of industry. ${ }^{3}$ The NGO and government categories started out closely matched in numbers, but government participation surged toward the end.

Labour's share of the leadership of the WGSR and its subsidiary bodies was even smaller than its share of overall WGSR membership. The chairs and vice-chairs of both the AHGCSR and WGSR were from industry. Labour experts held only one of around 20 leadership positions within the WGSR for the first two and a half years. Then, even as labour's share of total WGSR membership began to increase, its share of leadership positions abruptly dropped to zero in late 2007 when three drafting task groups were replaced by a single Integrated Drafting Task Force (IDTF).

Labour interests were also advocated by the ILO in the WGSR. The ILO was formally categorized as government but it was there to protect and promote international labour standards and its own authority to promulgate and interpret them. ILO representatives participated in several key subgroups, including the Chair's Advisory Group (CAG), IDTF and Editing Committee.

\subsection{Labour's Unlikely Success}

Despite being vastly outnumbered in the WGSR and eventually excluded from formal leadership positions, labour secured remarkably favourable results in ISO 26000 in comparison to leading SR initiatives developed by other business-oriented organizations. The foremost labour representative in the WGSR, Dwight Justice of the International Trade Union Confederation (ITUC), called ISO 26000 'the best concise, yet comprehensive, statement on social responsibility and labour to date,' and a 'welcome antidote' to the tendency of many CSR initiatives to dilute firms' responsibilities to workers (Justice 2011, 31).

Like most SR initiatives, ISO 26000 embraces the ILO's four fundamental rights at work: freedom of association and the right to collective bargaining; the elimination of forced labour; the effective abolition of child labour; and the elimination of discrimination with respect to employment and occupation. But unlike many SR initiatives, ISO 26000 makes clear that social responsibility embraces a wide range of other labour-related rights, including the right to freely chosen work, the right to work in just and favourable conditions, the right to a standard of living adequate for the physical and mental health and well-being of the individual and his or her family, and the right to social protections such as unemployment, illness, disability, old age and bereavement benefits (clause 6.3.9.1).

To test Justice's favourable assessment, I compared ISO 26000's treatment of labour issues with other leading contemporary SR initiatives on one hand, and with the ILO's own articulations of the ILSs on the other. ${ }^{4}$ I will only sketch the key findings here; a detailed description is beyond the scope of this chapter. ISO 26000 covered a far wider range of labour issues than other leading contemporary SR initiatives, including the UN Global Compact, Social Accountability International's SA8000:2008 standard (Social Accountability International 2008) and the Business Social Compliance Initiative (BSCI) Code of Conduct (Foreign Trade Association 2009)..$^{5}$ At a substantive level, ISO 26000's articulation of organizations' responsibilities in relation to the four fundamental rights at work was more ambitious than that of $\mathrm{SA} 8000$ or $\mathrm{BSCl}$, and far more detailed than the 
Global Compact's bare-bones treatment. ISO 26000 compared even more favourably to these leading contemporary SR initiatives on issues beyond fundamental rights at work. On wages, working conditions and occupational health and safety, SA8000 and $\mathrm{BSCl}$ exhibited more weaknesses than strengths when compared to ISO 26000. These initiatives were almost entirely silent on an array of other labour standards articulated in ISO 26000, including employment promotion, employment security, training, benefits, tripartite consultation, employment policy and community development. The official guide to the Global Compact's labour principles was almost completely silent on labour standards beyond the four fundamental rights at work (International Labour Organization 2008).

ISO 26000 also came much closer to reflecting the ILO's own articulation of ILSs than did other contemporary SR initiatives. ISO 26000 came closer than SA8000, the BSCI and the Global Compact's labour guidance to matching the scope, specificity and rigour of the ILO's pronouncements across the full range of ILSs. By my reckoning ISO 26000 even exceeded the ILO's own articulation on a significant minority of issues, including the forms of child labour to be eliminated (all rather than the worst), steps to remediate children removed from work, actions to combat employment discrimination, OHS management principles and practices, equity dimensions of OHS risks, psychosocial hazards, employment policy, work-life balance, overtime, respect for law and international norms, and the scope of social responsibility.

The latter two strengths are worth noting. First, ISO 26000 and the ILO's Tripartite Declaration of Principles Concerning Multinational Enterprises and Social Policy (ILO MNE Declaration) (International Labour Organization 2006) both stated that organizations should comply with applicable laws and regulations, respect relevant international standards and honour voluntary commitments. But the ILO MNE Declaration put more emphasis on respect for states' sovereign rights, did not mention collective agreements amongst the commitments firms should honour, and failed to guide firms on how to handle conflicts between national law and international standards. ISO 26000 , by contrast, urged that where the law or its implementation is inadequate, an organization should strive to respect international norms as a minimum floor; and where the law or its implementation conflicts with international norms, it should respect the latter to the greatest extent possible, review its relationships and activities, try to influence others to remedy the conflict, and avoid being complicit in other organizations' activities that are inconsistent with international norms. ISO 26000 was even more specific where labour standards were concerned, saying that an organization 'should ensure that the conditions of work comply with national laws and regulations and are consistent with applicable international labour standards, ... should respect higher levels established through other legally binding instruments such as collective agreements, [and] should observe at least those minimum provisions defined in international labour standards as established by the ILO, especially where national legislation has not yet been adopted' (clause 6.4.4.2). Significantly, this expectation applied to all ILSs, regardless of their ratification status. ISO 26000 was more demanding in this respect than the Global Compact's labour guidance, SA 8000, or BSCl.

The second strength of ISO 26000 worth emphasizing was its treatment of the organizational scope of social responsibility. The ILO MNE Declaration and ISO 26000 agreed that organizations have a responsibility both to avoid harm and to contribute positively to economic and social progress. But whereas the ILO MNE Declaration spoke of the responsibility of various organs within a multinational enterprise, ISO 26000 extended an organization's responsibility beyond its formal boundaries to encompass 'all policies and practices relating to work performed within, by or on behalf of the organization, including subcontracted work' (clause 6.4.1.1). ISO 26000 went even 
further to stipulate that in some circumstances an organization has a responsibility to exercise leverage over other actors within its sphere of influence, either to enhance positive impacts or minimize negative impacts. In relation to labour practices, an organization 'should make reasonable efforts to encourage organizations in its sphere of influence to follow responsible labour practices, recognizing that a high level of influence is likely to correspond to a high level of responsibility to exercise that influence' (clause 6.4.3.2). ISO 26000's expectations regarding leverage and sphere of influence went beyond those in the ILO MNE Declaration, SA 8000, BSCl and the Global Compact labour guidance. ${ }^{6}$

ISO 26000's relatively strong treatment of labour standards was recognized by labour experts and the ILO. Labour experts in the WGSR repeatedly applauded the draft standard's definition of social responsibility, its consistency with the ILSs, its deference to the ILO, its comprehensive yet concise account of responsible labour practices, its suitability for all organizations, its respect for authoritative intergovernmental instruments, its failure to endorse private voluntary initiatives, its repudiation of organizations' self-definition of their responsibilities and its overall length and detail. The ILO's comments were similar. It expressed strong support for the guide's treatment of labour practices and labour-related human rights, declaring these sections to be concise and fully consistent with ILSs and the ILO MNE Declaration. Only at the final vote did the ILO curb its enthusiasm, opining merely that the finished product did 'not appear to conflict with international labour standards as currently understood and applied' (ISO 2010a, para. 4).

With this account of labour's disadvantage and against-the-odds success in the development of ISO 26000 in mind, I now investigate what factors might have contributed to this result.

\section{Understanding Labour's Success}

How did labour succeed in securing in ISO 26000 a 'comprehensive distillation of responsible labour practices' (International Trade Union Confederation 2010) that was unprecedented in global CSR initiatives? Effective leadership, transnational organization, strategic concentration of limited resources and relative homogeneity of interests played a part, but other stakeholder categories also enjoyed these advantages along with greater numbers and resources. The key to labour's success appears to have been its ability to take advantage of the delicate relationship between ISO and the ILO at a moment when ISO needed the legitimation that the ILO could offer. These ISO-ILO interactions went through three phases corresponding to three components of a regulatory governance process: agenda setting, including forum selection; norm formation within the selected forum; and evaluation and review (Eberlein et al. 2014, 6-7).

\subsection{Agenda Setting and Forum Selection: Remaking the ISO-ILO Relationship}

The initial interaction between ISO and the ILO in the field of SR mainly concerned putting the topic of SR on ISO's agenda. This interaction destabilized the existing ISO-ILO relationship and tentatively formalized a new one.

ISO and the ILO had a longstanding relationship in which the ILO participated in and occasionally initiated the development of ISO standards affecting the workplace. This collaboration was restricted to what the ILO viewed as narrow technical standards. This relationship came under pressure in the mid 1990s when the British Standards Institution (BSI) lobbied to internationalize its own occupational health and safety management system (OHSMS) standards through ISO. ISO initially declined in the face of objections that the ILO was a more appropriate forum. The ILO began 
work on its own OHSMS guidelines in 1997. ${ }^{7}$ BSI forged ahead with an international OHSMS standard outside ISO, which was published in 1999 as OHSAS 18001. BSI then proposed a new ISO technical committee to develop OHSMS standards based on OHSAS 18001. The ILO and its labour and employer constituencies opposed what they viewed as ISO's competing initiative. The BSI proposal failed and the ILO's OHSMS Guidance was published in 2001 (International Labour Office 2001). ${ }^{8}$

ISO's initial exploration of SR standardization further destabilized the ISO-ILO relationship. The 2002 COPOLCO report endorsing the feasibility of ISO SR standards gave little attention to workers and did not recognize the ILO's distinctive mandate. The ILO and labour unions worried that ISO, whose standards were driven by trade liberalization and market demand rather than pursuit of social justice, might not fully respect the ILO's authority or uphold its standards (International Labour Organization 2007). When ISO created the AHGCSR to advise it on the subject, the ILO and the International Confederation of Free Trade Unions (ICFTU, ITUC's predecessor) participated defensively. With the intervention of the the ILO's Hans Hofmeijer and the ICFTU's Dwight Justice (both of whom later participated in the WGSR), the AHGCSR recognized that the 'ILO is the only intergovernmental body that was created specifically to develop international labour standards,' that 'ISO is not an intergovernmental organization and therefore cannot define on its own substantive expectations in the area of social responsibility,' and that 'ISO must recognize and respect the legitimacy and competence of existing bodies that have been setting SR standards for many years or decades - in particular the ILO and other UN bodies' (ISO 2004c, 50-51). The AHGCSR recommended that ISO should develop SR standards only if it recognized its lack of authority to set social expectations properly defined by representative political institutions, the difference between private voluntary initiatives and authoritative intergovernmental instruments, and the ILO's unique mandate to define international standards on a broad range of issues affecting workers (ISO 2004b, 1).

ISO accepted most of these recommendations. Realizing that it needed the ILO's support or acquiescence to legitimize its move into SR standardization, it approached the ILO to work out an agreement for the ILO to participate in ISO'S SR work. The two organizations signed a Memorandum of Understanding (MOU) three days before the WGSR's first meeting (International Organization for Standardization and International Labour Organization 2005). The MOU gave the ILO unprecedented procedural and substantive rights within ISO. At a substantive level, it promised that any ISO SR standard would be 'fully consistent with' and 'in no way detract from' the ILSs and their interpretation by ILO organs (ibid., Article 2.1). It also made ILO instruments 'the authoritative and definitive source of reference and minimum baseline' for any elements of an ISO SR standard relating to labour standards (ibid., Article 6.1). This was a significant departure not just for ISO but also for the ILO. Up to this point, certain core ILSs were widely considered a minimum floor for all ILO member states even if they had not ratified the relevant Conventions. Now ISO was promising to extend the same treatment to all ILO instruments regardless of ratification status. Never before or since has ISO provided such an ex ante guarantee as to the content of its standards.

Moving to procedural safeguards, the ILO secured the right for itself and its tripartite constituency to participate fully in all ISO bodies concerned with any ISO SR standard. The MOU also gave the ILO the right to review and comment on any proposed text that implicated ILO issues before the text was circulated within the WGSR, and to have its comments circulated with the proposed text. ISO agreed to seek the ILO's full and formal backing for any draft standard before circulation to ISO member bodies for ballot or comment, and if such backing was not forthcoming, to circulate the ILO's comments together with the draft prior to any ISO vote. 
The only quid pro quo for ISO's concessions was the ILO's implicit acquiescence in ISO's claim to be a suitable forum for SR standards development. Even this acquiescence was limited: the MOU stated that ILO participation in ISO's SR standardization activities did not imply endorsement of any ISO standard and was conditional upon ISO's performance of its obligations under the MOU. That ISO extracted no concessions from the ILO other than this limited acquiescence indicates the strength of its need to reach an agreement and the fragility of its claim of authority to develop SR standards.

On its face, this transaction looked one-sided in the ILO's favour. ISO gave the ILO unprecedented privileges within ISO in return for the ILO's grudging acquiescence in ISO's decision to develop SR standards. But the benefits for ISO were substantial: ISO gained access to the ILO's legitimacy, authority and expertise, not to mention its pre-existing corpus of labour standards. By contrast, the risks for the ILO were substantial, mainly in the form of potential dilution of the ILO's authority and standards. But cooperation with ISO also offered the ILO potentially greater penetration of ILO standards in the global business community through ISO's worldwide network of standards developers and users.

While much of the credit for these procedural and substantive protections for the ILO goes to the ILO itself, some goes to organizations representing the ILO's labour and employer constituencies. The ICFTU, the International Organization of Employers (IOE) and their respective member organizations played important roles in the AHGCSR and beyond, expressing opposition to ISO's development of SR standards and lobbying for a special role for the ILO and its standards should ISO go ahead. Without their efforts it is not clear that ISO would have given the ILO the privileges it did in the ISO-ILO MOU.

Another preliminary issue was resolved during this agenda-setting phase that related closely to the ISO-ILO relationship: whether ISO would need to modify its standard-setting processes to enter the SR arena. COPOLCO thought that existing ISO rules could accommodate meaningful and balanced participation of the full range of stakeholders. The AHGCSR was less sanguine. Some members thought that existing ISO rules could accommodate a suitable range of stakeholder participation and that modifications would undermine ISO's reputation for technical expertise. Others argued that ISO's normal processes could not secure meaningful participation from all relevant actors; that consultants were overrepresented on ISO member body delegations; and that liaison membership did not confer adequate rights. An even more fundamental objection, traceable to the ILO and organized labour, was that standard-setting on social issues such as SR requires representative structures, which ISO lacked, and that ISO should therefore not engage in this kind of standard-setting.

In the end all the AHGCSR could agree on this point was that ISO should proceed with SR standardization only after it reviewed its processes and made adjustments where necessary 'to ensure meaningful participation by a fuller range of interested parties' (ISO 2004b). Acting on this recommendation, ISO asked its member bodies to nominate experts in six stakeholder categories, instructed the WGSR to ensure the openness and transparency of its activities (which the WGSR did by posting all its records publicly on the Internet) and urged the WGSR to ensure balanced representation of stakeholder groups in all of its subgroups.

By the time the WGSR first met in March 2005, the framework was in place for a new ISOILO relationship. Instead of occasional ad hoc cooperation on a limited range of technical issues, the ILO was now preparing for sustained participation in ISO standard-setting on contested matters of social policy. The MOU formalizing this new relationship gave the ILO procedural and substantive 
guarantees not enjoyed by any other participant in ISO standard-setting before or since. To secure the ILO's cooperation, ISO promised that any ISO SR standards would be fully consistent with the ILO's labour standards as interpreted by the ILO, and that they would treat ILO standards as a floor even in the event of conflict with national law. ISO also agreed to seek the ILO's support before circulating any draft text to the WGSR for comment or vote, and to circulate any ILO comments to the WGSR along with the draft text. Alongside this formal agreement, ISO made several decisions that helped secure the ILO's cooperation, including that ISO 26000 would be a guidance standard (not for certification), would not be a management system standard, would recognize the difference between authoritative intergovernmental instruments and voluntary private initiatives, would not address issues that could only be resolved through representative political processes, and would be developed through an open and transparent process designed to ensure meaningful participation of a full range of interested parties.

Organized labour played a significant part in working out the terms of this new relationship. Although there was only one labour representative on the AHGCSR and none on COPOLCO or the TMB, labour's influence was magnified by ISO's legitimation deficit in the SR field and the wide recognition (including by major employer groups) of the ILO as the authoritative source of international labour standards. These factors also put labour in a good position to take advantage of the new ISO-ILO relationship in its favour during the drafting of ISO 26000.

\subsection{Norm Formation: Leveraging the new ISO-ILO Relationship}

With the shift from agenda-setting and forum selection to norm formation, the dynamics of governance interactions changed. The earlier phase was characterized by interactions amongst a small number of actors. The new phase was much more dynamic and open-ended and involved many more participants interacting within and outside a forum - the WGSR - that quickly took on a life of its own. During this phase, labour leveraged ISO-ILO interactions in two ways. First, it rode a wave of support for the ILO and the ILSs built up by participants from all stakeholder categories and by the ILO itself. Second, labour actively promoted the ILO's special status to advance its own interests. Through this combination of passive and active piggy-backing (Buhmann 2015), labour prevailed on most of the issues that mattered to it.

One might be tempted to discount organized labour's role in this case on the basis that the result would have been the same regardless of its actions. The ILO was responsible for the gains for labour in ISO 26000; organized labour simply tagged along. I argue that this would be incorrect for two reasons. First, it would be inaccurate factually. While the ILO was self-assertive in the negotiations leading to ISO 26000, its labour constituency was an important source of support and exercised significant influence of its own in both the agenda setting and (as I will argue) norm formation phases. Without the active support of its labour and employer constituencies, it is doubtful that the ILO would have enjoyed the influence it did within ISO.

Second, to characterize labour's role as insignificant because it did not substantially influence the regulatory outcome would miss the point of my argument. The point is not that ISO 26000 would have been different but for organized labour's efforts - although I think it would. The point is that organized labour took advantage of governance interactions between ISO and the ILO in a manner that advanced its interests. Taking advantage can entail actively steering and shaping interactions, or it can mean simply hitching one's wagon to someone's star and going along for the ride. Conservation and efficient use of regulatory resources are priorities for all regulatory actors. They are especially so for marginalized actors facing severe resource constraints. The fewer precious 
resources such an actor must expend to achieve a given regulatory outcome, the better for it. From this perspective, the most successful strategy is one in which the actor achieves a given result without expending any resources. Finding suitable coattails to ride, jumping aboard, hanging on and knowing when if at all to jump off are important strategic questions for such actors. In such a case the actor cannot claim to have determined or even to have influenced the outcome, but it has still taken advantage of a particular constellation of governance interactions to advance its interests.

With this preliminary objection out of the way, I start by describing organized labour's passive riding of the ILO's coattails. Labour benefitted from a widely shared deference to the ILO's special status. Even before the WGSR first met, many ISO member bodies and experts highlighted the need to cooperate with the ILO and respect its instruments. One of the WGSR's first acts was to acknowledge the ILO's special status and promise to consult it continually to ensure effective and timely implementation of the ISO-ILO MOU. As the WGSR began its work, deference to ILO core labour standards and other authoritative international instruments was a frequent theme across stakeholder groups.

ILO representatives reinforced these points, emphasizing the ILO's history as a CSR pioneer, its mandate to promulgate international labour standards, and its representativeness. They laid down some bottom lines very early, including that the ILO Declaration on Fundamental Principles and Rights at Work was an 'absolute minimum that cannot be questioned' (ISO 2005 Annex D), that ISO 26000 must be fully consistent with the ILSs, that it must distinguish clearly between authoritative intergovernmental instruments and private initiatives, and that the ILO could not possibly agree to a standard that promoted or endorsed any private initiatives. Although the ILO was assertive, it did not support proposals that exceeded its interpretation of the rights and protections for labour in existing ILO instruments. It urged the WGSR to tone down excessive formulations of social responsibility to avoid overwhelming and discouraging organizations. It urged clarification that organizations should respect the principles of international labour standards and other authoritative intergovernmental instruments, not that they must comply with them directly.

Even participants who wished to scale back protections for workers tended to treat ILO instruments as the benchmark for labour standards. The Malaysian delegation, for example, commented:

We do not want the ISO to get into the business of setting labour standards. This is why we want the text to be closely related to existing ILO standards. Therefore this is not the place to promote a 'wish list' of things that we would want but haven't been able to get at the ILO (ISO 2008, 391).

Very few participants were openly skeptical of the ILO and its standards. A few industry and government participants proposed, unsuccessfully, to delete references to ILO instruments and eliminate the entire section on fundamental rights at work. Others argued that ISO 26000 should reflect only widely ratified ILO instruments. This latter argument sometimes prevailed, for example when the IOE lobbied successfully to remove text drawn from an ILO convention that was ratified by just 35 countries.

Not only did many participants invoke ILO standards as the touchstone for their positions on labour issues, they also deferred to the ILO's expertise on these matters. Numerous experts urged having the ILO rewrite provisions related to labour, and at one point the ILO did so at the request of the Integrated Drafting Task Force. This fact was raised by experts from various stakeholder groups as a reason to reject subsequent proposals to scale back protections for workers. 
In short, what makes this case noteworthy is that so many participants justified their positions in terms of consistency with ILO standards and deference to the ILO's authority. This atmosphere helped organized labour immensely. It meant that the basic labour rights and standards included in most other SR instruments and initiatives were not concessions to be secured through bargaining but a taken-for-granted foundation. This combination of factors operated as a kind of ratchet so that gains for labour continued to accumulate throughout the negotiations even in the face of sustained resistance from some industry and government participants.

Labour experts did not merely ride this wave, they sought proactively to leverage the ILO's special status in their favour. Throughout the negotiations, labour experts emphasized the ILO's unique mandate and urged full implementation of the ISO-ILO MOU. They lobbied successfully for references to numerous ILO instruments, including many that were not widely ratified. They urged repeatedly that organizations should observe ILSs even when they conflict with national laws. They insisted that ISO 26000 refer only to authoritative intergovernmental instruments for relevant principles and standards. When they were happy with a draft's treatment of labour issues, they invoked its consistency with ILO standards as a reason to keep it. Commenting on the first full working draft, for example, labour experts observed:

Importantly all of [the labour practices clause] can be related to legitimate expectations and principles in international instruments of the ILO. It does not create any new expectations and therefore it does not replace the ILO and its function of setting international labour standards (ISO 2007, 2, 4).

All of this occurred against the background of widespread recognition that labour was underrepresented and disadvantaged in the negotiations. WGSR participants recognized this disadvantage early on. The ICFTU (which later became ITUC) pointed out that the WGSR's process did not ensure balanced participation of all relevant interests. It lobbied to qualify the statement in ISO 26000's draft introduction that ISO 26000 was developed through a multi-stakeholder process, opining that experts were appointed 'without sufficient checks on criteria to be credible' and that the WGSR's procedures 'would have to be significantly revised in order to be considered a genuine multi-stakeholder process' (ISO 2008, 60). The IOE agreed. Ultimately a caveat was added that 'a full and equitable balance of stakeholders was constrained by various factors' (ISO 26000, foreword).

Despite labour's disadvantage, it was viewed by WGSR participants as second only to industry in influence, according to a 2008 survey (Schmiedeknecht 2008, 16). Survey respondents attributed labour's disproportionate influence to the ISO-ILO MOU (ibid., 18-19). Labour experts achieved substantial success on most major issues on which they took public positions in the negotiations, and many of their efforts to invoke the ILO's authority or standards to justify expanding workers' rights and protections beyond the ILO's core labour standards succeeded. Industry participants frequently resisted this expansion, but they lost most of the battles they waged on this front. Furthermore, most efforts (by industry, government, consultants and ISO member bodies) to use ILO standards to justify lowering workers' rights and protections also failed.

Even as labour passively benefited from and proactively leveraged the special relationship between ISO and the ILO during the negotiation of ISO 26000, ISO and the ILO began to review and evaluate their arrangement. 


\subsection{Evaluation and Review: Reconsidering the ISO-ILO Relationship}

ISO and the ILO began to reconsider their relationship even before the drafting of ISO 26000 was finished. The conditions that enabled labour to leverage the ISO-ILO relationship to its advantage did not survive the WGSR. My goal here is simply to sketch these developments briefly.

In the late stages of the WGSR's work, ISO struck a high-level group to consider whether ISO should apply the WGSR's innovations, including representation by stakeholder groups and enhanced rights for external organizations such as the ILO, to other ISO standards development. The group received highly positive feedback about these innovations from most WGSR participants but negative feedback from many ISO national member bodies, which felt that the WGSR's special arrangements undermined their authority as the primary loci for stakeholder input. The high-level group agreed. It recommended that ISO not change its established procedures and that stakeholder engagement occur within ISO national member bodies (ISO 2011, 5).

The ILO had its own second thoughts about the WGSR experience. It voiced concern within the WGSR and in ILO organs about the time and resources required to participate effectively, the risk that tripartite dialogue would be compromised when the WGSR switched to commenting and voting by ISO national member bodies rather than by individual experts, and the risk that ISO SR standards might be used for private third-party certification in competition with ILO instruments. Within the ILO, employer and worker constituents expressed concern that ISO 26000 could be misused, its publication could lead to a proliferation of standards developed by bodies lacking formal tripartite representation, such private standards could undermine the ILO's exclusive competence to set international labour standards, and ILO standards could be hijacked by profitseeking standardization and certification bodies.

During the development of ISO 26000, some ISO member bodies proposed other ISO standards that would address ILO issues including occupational health and safety and human resource management. The ILO repeatedly voiced its resistance to such standards and its determination to participate only if afforded appropriate guarantees like those in the ISO-ILO MOU. ISO deferred to the ILO in some cases but went ahead in others-specifically, human resource management standards-without ILO participation.

In 2013, ISO finally accepted BSI's latest proposal to develop an ISO OHSMS standard, to be known as ISO 45001. ISO and the ILO concluded a new MOU in relation to this standard. This agreement was substantially weaker than the $2005 \mathrm{MOU}$. It provided merely that ISO standards 'should respect and support' the ILSs. It gave the ILO less extensive procedural rights than the 2005 MOU and did not promise to seek the ILO's full and formal backing of draft ISO standards (International Organization for Standardization and International Labour Organization 2013). The ILO was soon disappointed with the implementation of the new MOU, complaining that the draft was inconsistent with the ILSs and that the committee's decision-making lacked transparency. ${ }^{9}$ The ILO's concerns were repeatedly dismissed by the leaders of the committee developing ISO 45001, who took the position that the committee could ignore the ILSs if that was its consensus. In the end, the ILO concluded that ISO 45001 was inconsistent with the ILSs. The ITUC and IOE also expressed severe reservations (International Trade Union Confederation 2017; International Organization of Employers 2017).

The ILO also believed that ISO neglected its obligation under the 2005 and 2013 MOUs to give the ILO adequate advance notice of any new proposed work implicating ILO issues, including a proposed revision of ISO 26000 . When the ILO suggested that any ILO participation in further ISO SR work would be governed by the $2005 \mathrm{MOU}$, ISO claimed that the $2013 \mathrm{MOU}$ had superseded the 
2005 MOU. To remove any doubt, in October 2017, ISO gave the ILO notice of termination of the 2005 agreement. Such was the ILO's frustration with this whole experience that it in turn terminated the $2013 \mathrm{MOU}$ and suspended all cooperation with ISO until further notice (International Labour Organization 2017a, 2017b).

How and why the ISO-ILO relationship fell apart is a question for another day. For now the important point is that the leverage that this special relationship conferred on labour within ISO may have been confined to a window in time when ISO's self-perceived legitimation deficit impelled it to seek to enroll the ILO and its regulatory resources (including authority, legitimacy, expertise and a pre-existing corpus of labour standards) to enhance its own regulatory capacities. By 2013, ISO did not feel this need in the field of OHSMS, and by 2017 it no longer felt it even in the broader field of SR.

\section{Lessons for Theory and Practice}

What lessons can be drawn from this case for efforts to advance marginalized actors' interests in transnational governance contests? In my case study, structurally weak actors-representatives of organized labour-were able to prevail in a transnational governance contest against more powerful adversaries-including representatives of industry and governments-by taking advantage of the uneasy relationship between one organization-ISO-that lacked certain regulatory resources (including legitimacy, expertise and regulatory standards) and another - the ILO-that could supply some of those resources. In this section I situate the findings of my case study in relation to the propositions about legitimation and enrolment stated in Part 1 . I then propose a triadic strategy to harness TBGIs to advance marginalized actors and improve the quality of transnational regulation. In this strategy an underdog exploits legitimation differentials between a regulator and a booster to advance its own regulatory agenda.

\subsection{Legitimation and Enrolment in the Case of ISO 26000}

In Part 1, I theorized TBGIs in terms of four propositions:

1. Regulators who claim legitimacy and the audiences of these claims are in a relationship of mutual autonomy and dependence;

2. In this relationship, regulators seek to secure legitimacy by creating, managing and manipulating audience perceptions and enrolling actors into desired regulatory roles;

3. It is, however, acceptance by audiences, often made up of multiple legitimacy communities, that ultimately confers legitimacy and secures enrolment; and

4. Legitimacy is shifting, variable and constantly renegotiated as regulators face multiple and conflicting legitimation demands.

On the first point, my case study revealed the mutual dependence and autonomy of ISO and its audiences. ISO perceived its authority to develop SR standards to be dependent on acceptance or at least acquiescence from certain audiences not limited to its core constituencies in the standardization and business communities. These wider audiences demanded that ISO conform to their expectations for legitimate authority. ISO perceived itself to be particularly dependent on the ILO, due to its representative political character and mandate to articulate authoritative labour standards. The mutual dependence and autonomy of ISO, the ILO and to a lesser extent organized labour were evident during the agenda-setting phase, when these three players (amongst others) hammered out the terms on which ISO's move into SR would be tolerated. They were also apparent 
during the norm development stage as organized labour took advantage of ISO's shaky legitimacy and the ILO's solid authority to achieve favourable regulatory outcomes in ISO 26000. After ISO 26000 was drafted, however, ISO's perception of its dependence on the ILO and organized labour waned to the point where it no longer felt the need for their acquiescence or support.

Turning to the second proposition, ISO relied mainly on a conforming legitimation strategy with the ILO and organized labour. It modified its normal rules to organize participation around stakeholder categories, publicize its records and confer unprecedented procedural and substantive rights on the ILO. The latter concession was part of an effort by ISO to enroll an external organization that was perceived as authoritative by almost all actors from whom ISO sought legitimation. The ISO/ILO MOU enabled ISO to enroll not only the ILO but also representatives of labour, industry, NGOs, governments and other stakeholders, who repeatedly cited the MOU as a prerequisite for the WGSR's work.

The ILO responded to ISO's strategies with its own legitimacy claims. It sought mainly to inform audiences in ISO and beyond of its authority. It emphasized its exclusive mandate to develop and interpret authoritative international labour standards, its representative political character and its tripartite structure. Organized labour asserted these same legitimacy claims for itself as one of the ILO's tripartite constituents, as did the IOE.

ISO sought to justify its development of SR standards by assuming special procedural and substantive constraints. The procedural constraints included a formal multi-stakeholder approach, transparent records and enhanced notice-and-comment rights for the ILO. The substantive constraints revolved around the principle that ISO would defer to norms set by representative political institutions and reflected in authoritative intergovernmental instruments. This principle had its strongest expression in the ISO/ILO MOU, which guaranteed that any ISO SR standard would be fully consistent with the ILSs and their interpretation by ILO organs and would treat ILO instruments as the authoritative reference and minimum baseline for labour standards. These constraints were largely observed in practice, with the exception of the multi-stakeholder approach. Many participants and observers were skeptical about experts' purported stakeholder affiliations and critical of the imbalance amongst stakeholder categories. Later, when the ISO 26000 project was coming to an end and audiences' attention was turning elsewhere, ISO reconsidered the WGSR model and-in the ILO's view - began to ignore the constraints of both the 2005 and the subsequent 2013 MOUs. These perceived transgressions eventually led the ILO to terminate its cooperation.

Before things got to this point, however, the legitimating constraints ISO took upon itself enabled it to enrol numerous actors into desired roles in ISO's rule-making apparatus. In turn it was able to mobilize the enrolled actors' symbolic and material resources in support of its goals. Aside from devoting time and money, these actors lent their expertise, connections and pre-existing norms to ISO. ISO's decision to defer to authoritative intergovernmental instruments for the content of key social responsibilities not only secured its legitimacy, it saved it the trouble of developing standards from scratch.

The third proposition in Part 1 was that it is ultimately acceptance by audiences, not strategic action by regulators, that confers legitimacy and secures enrolment. The case study supported the proposition that audiences' abilities to affect a regulator's legitimacy vary, as do the bases on which they grant or withhold legitimacy. The ability of the ILO to affect ISO's legitimacy in the field of SR was substantially greater than that of labour unions alone, due to the former's organizational resources and high legitimacy in the eyes of a broad audience (Tamm Hallström and Boström 2010, 145). Likewise, ISO's core constituencies of transnational corporations, national standards bodies 
and service providers had greater influence than more marginal audiences like labour. That said, the tight coherence of the labour stakeholder group around a single lead organization, ITUC, enhanced its influence over ISO's legitimacy compared to heterogeneous, less organized stakeholder groups (ibid., 127-128).

The ILO and organized labour responded to ISO's legitimation strategies initially with hostility because they believed ISO was dominated by big business and unlikely to uphold international labour standards. Later, ISO's conforming strategies brought them around to cautious acquiescence. Simply by participating, they conferred a certain degree of legitimacy on ISO, but this legitimacy was contingent upon achieving an acceptable outcome. In the end both the ILO and ITUC were satisfied with the content of ISO 26000. It was no surprise, however, that this legitimacy was not very resilient to ISO's perceived transgressions in the aftermath of the WGSR. In the subsequent development of ISO 45001, ISO's central organs and the leaders of the OHSMS committee appealed to a more traditional basis for ISO's legitimacy: technical expertise in the service of business. This may have secured legitimacy from most participants, but it failed to secure legitimacy from the ILO or organized labour.

The case study also amply supports the final proposition in Part 1, that legitimation requires management of multiple, often conflicting, demands. The case sheds light on the question of which legitimation demands regulators will heed or ignore. Recall that Black suggests that this will not be a simple matter of the anticipated legitimacy gains for the regulator. Rather, a regulator will be more likely to accept an audience's legitimation demands 'where it perceives itself to have a relatively high dependence on or interconnectedness with the legitimacy claimant; where the content of the claim and the discourse in which it is expressed is congruent with the organization; where acquiescence would not pose severe constraints on its discretion; where the claimant can directly or indirectly coerce the regulator; where the claims being advanced are widely diffused; and the consequences of acquiescing are relatively certain' (Black 2008, 156).

Before applying these factors to my case, I propose a seventh factor. In saying that anticipated legitimacy gains do not determine regulators' responses to audience demands, Black focuses on legitimacy gains with the particular audience making the demand. It is true that ISO did not expect to gain a great deal of legitimacy with the ILO or organized labour as a result of accommodating their legitimation demands. It expected them to tolerate and take part in ISO's work, little more. But it expected enrolment of the ILO to garner substantial legitimacy for ISO with other audiences, and in fact it seems to have done so. I would therefore add a seventh factor to Black's hypothesis, namely the anticipated overall legitimacy gains for the regulator from all audiences as a result of acceptance of the particular audience's demands. The greater the overall gains, the more likely the regulator is to accept the demands.

Applying these factors to my case study reveals a puzzle in the case of organized labour: four of seven factors appeared neutral at best, and three clearly disfavoured ISO's acquiescence to organized labour's demands; yet most of labour's procedural and substantive demands were met in the drafting of ISO 26000. I start with the four factors that did not clearly work against labour. First, accepting organized labour's legitimacy demands would place significant but not severe constraints on ISO's discretion. Labour essentially advanced the same demands as the ILO: that ISO 26000 would be fully consistent with and in no way detract from the ILSs as interpreted by the ILO, that ILO instruments would be the authoritative reference and minimum floor, and that ISO 26000 would recognize the primacy of authoritative intergovernmental instruments. These were significant constraints, but ISO reserved the discretion to determine which labour issues to include, 
which instruments to cite, the form of the standard (guidance or certification), its normative strength ('shall,' 'should' or 'may'), and its detail and precise wording. ISO also made procedural concessions to secure the cooperation of labour and the ILO. These were significant but ultimately modest departures from ISO norms. The ISO Directives already required committees to seek the full and formal backing of all liaison organizations for draft standards; the main exception was to give the ILO earlier and more extensive rights to notice and comment. Another procedural modification was the right for labour, employers and the ILO to participate fully in all ISO bodies concerned with any ISO SR standard. But this was a minor concession: the ILO, IOE and ITUC would surely have been accepted in the WGSR as liaison organizations under ISO's ordinary rules. Beyond these ILO-specific modifications, ISO organized participation around six stakeholder groups and guaranteed them seats on most key subsidiary bodies. This did not turn the WGSR into a genuine multi-stakeholder forum, however. Stakeholder groups were highly uneven in numbers, resources and tenure of leadership positions; many national mirror committees did not have balanced representation; the authenticity of some experts' stakeholder credentials was disputed; and ISO member bodies, not individual experts, voted on drafts. The WGSR's transparency innovations were also modest: records were posted publicly, but meetings were closed to the public and media. These constraints, taken together, can be considered substantial but not severe. This factor therefore did not clearly disfavour ISO's acquiescence to the demands of organized labour.

A second factor that appeared neutral was the diffusion of organized labour's legitimacy claims in ISO's institutional environment. These claims were widely diffused in ISO's external environment insofar as they reiterated the ILO's claims of authority to set labour standards and asserted a general norm of balanced and effective participation by all stakeholder categories. But they were not widely diffused insofar as labour claimed special status distinct from other stakeholder groups. The idea that any stakeholder was more important than others was not prevalent in the standardization community except in relation to industry, the primary user of standards.

Third, the consequences of acquiescing to organized labour's legitimation demands were somewhat uncertain, given the multiplicity of actors representing labour and the absence of a written agreement setting down the terms of their engagement. That said, they overlapped substantially with the ILO's demands, the consequences of which were relatively certain: acquiescence would enable ISO to proceed with developing SR standards within agreed procedural and substantive constraints. This factor was therefore either neutral or modestly favourable to organized labour.

A fourth factor that did not clearly disfavour labour was the anticipated overall legitimacy gains for ISO from all audiences as a result of acceptance of labour's demands. Representatives from all stakeholder categories frequently emphasized the importance of respecting labour standards and having labour on board. But most of their attention was directed at the ILO, and it is not clear that any legitimacy gains with these wider audiences could have been attributed specifically to ISO's acceptance of the demands of organized labour as distinct from those of the ILO.

The remaining three factors clearly disfavoured ISO's acceptance of labour's legitimacy demands. First, ISO saw the benefit of having organized labour on board but did not seem to perceive itself as particularly dependent on organized labour for the performance of its regulatory role; nor did it appear to feel much sense of inter-organizational or interpersonal connection with organized labour, in contrast to its lengthy ad hoc collaboration with the ILO. Second, the congruence of organized labour's legitimation demands with ISO's own cognitive and normative 
frameworks was low. ISO sits at the apex of a system of voluntary standardization rooted in an ideology of technical expertise, voluntarism, free enterprise and trade liberalization (Wood 2003, 2005; Murphy and Yates 2009). Labour formulated its claims in terms of social justice, workers' rights, tripartite dialogue, democratic accountability and limitation of unbridled markets. Finally, organized labour had very limited means to coerce ISO to accept its demands. It could not credibly threaten to sanction ISO for non-compliance with its requirements except by walking away. It relied on persuasion and ISO's goodwill. This became clear later, when ISO ultimately forged ahead with a process and outcome for ISO 45001 over the objections of ITUC, IOE and the ILO.

Why, then, did ISO more or less accept organized labour's legitimacy demands? The answer seems to be that organized labour was able to ride on the ILO's coattails. Five of the seven factors favoured ISO's acquiescence to the ILO's demands. First, when ISO launched its SR work, it perceived itself to be dependent upon the ILO for the ability to write SR standards affecting labour issues. It also seems to have seen itself as interconnected with the ILO by virtue of their overlapping activities in OHS and other labour-related issues, their history of ad hoc cooperation, their shared status as influential, venerable, non-partisan international organizations devoted to the betterment of society, and the overlap of their business/employer constituencies. Black's first factor thus favoured the ILO.

The congruence of the ILO's legitimation demands with ISO'S cognitive and normative frameworks was greater than it was for organized labour. In addition to social justice, workers' rights, tripartite dialogue and democratic accountability, the ILO couched its claims in terms of its own political representativeness and authority to promulgate binding international law. This resonated with ISO's understanding of its own limitations: voluntary standards should eschew politics and should not conflict with authoritative legal norms set by representative political authorities. During the negotiation of the ISO/ILO MOU, ISO said that it was 'in ISO's own interest not to develop standards that conflict with national or international law' (Anonymous 2005, on file with author). This factor therefore modestly favoured acquiescence to the ILO's demands.

Black's third factor was probably neutral in that acquiescence to the ILO's demands posed substantial but not severe constraints on ISO's discretion. I discussed this factor earlier in relation to organized labour. Fourth, like organized labour, the ILO lacked the means to coerce ISO to accept its demands. This factor therefore disfavoured ISO's acquiescence to these audiences' demands. Fifth, the ILO's legitimacy as the authoritative source and interpreter of ILSs were very widely diffused in ISO's external environment, favouring acquiescence to its demands. Finally, the consequences of acquiescing to the ILO's legitimation demands were more certain than those of labour alone. Acquiescence would enable ISO to proceed with developing SR standards within the constraints described earlier. It would secure the ILO's participation in the WGSR. Finally, as I argued above, it promised to deliver substantial legitimacy gains with other audiences including government, NGOs and industry.

In short, conditions favoured ISO's acquiescence to the ILO's demands but not organized labour's. Organized labour appears to have taken advantage of the ILO's stronger position to secure gains it probably could not have achieved on its own. What strategic lessons can be drawn from this success?

\subsection{Harnessing TBGIs by Leveraging Legitimation Differentials}

My case study suggests a triadic strategy for disadvantaged actors to prevail in transnational governance struggles by leveraging the legitimation differential between a regulator facing a 
legitimacy deficit and another actor with abundant legitimacy. In my case study, ISO pursued a forum-shifting strategy, proposing itself as an alternative to existing international SR standardsetting arenas. It supported this shift with a conforming legitimation strategy aimed at accommodating, or being seen to accommodate, the concerns of certain audiences that resisted the shift. It employed a mix of contractual and organizational modalities to achieve this accommodation: contractual in the form of MOUs with the ILO, UN Global Compact and OECD; organizational in the form of enticing actors to work within ISO with the promise of modified standard-setting rules and procedures.

Organized labour came to this alternative forum reluctantly and faced a substantial disadvantage there. Moreover, ISO had little reason to accept organized labour's legitimation demands. And yet labour achieved a remarkably favourable outcome in the form of the labourrelated content of ISO 26000. It did so by taking advantage of the uneasy relationship between an organization-ISO-that lacked certain important regulatory resources (including legitimacy, expertise and pre-existing regulatory standards) and another-the ILO-that could supply those resources.

This case suggests a generalizable strategy in which a weak actor magnifies its impact by exploiting the interaction between a regulator with a legitimation deficit and an actor with what might be termed a legitimation surplus. The strategy I describe shares some features with but is distinct from other triadic models of regulatory governance such as orchestration (Abbott and Snidal 2009; Abbott et al. 2015a) and regulatory intermediaries (Abbott, Levi-Faur, and Snidal 2017). The first condition for the strategy is the presence of an actor who wishes to achieve regulatory goals but finds itself at a systematic disadvantage that it cannot overcome on its own. This actor might be a beneficiary of regulation, a target, or otherwise interested in the regulation. I will call this actor the underdog.

The second condition is that the regulator the underdog wishes to influence has a legitimation deficit with audiences, other than the underdog, from whom the regulator seeks legitimacy. Such a legitimation deficit gives the regulator an incentive to seek to enrol actors to endow it with the legitimacy it lacks. In turn it creates an opening for those actors to influence the regulator in ways that might help the underdog. Underdogs may be able to widen this opening by accentuating this legitimation deficit-something that organized labour did in the context of ISO's move into the SR field. Such delegitimation tactics may be insufficient on their own to achieve the underdog's goals, but can be part of the underdog's strategy. The regulator in this model is similar to that in the orchestration and RIT (regulator-intermediary-target) models in that it lacks capacities needed to achieve its regulatory goals (Abbott et al. 2015b; Abbott, Levi-Faur, and Snidal 2017). What is distinctive about my account is that one of these capacities must be legitimacy, though they can also include others such as expertise, operational capacity, and pre-existing regulatory standards.

The third condition is the presence in the regulator's environment of an actor that enjoys high legitimacy and is amenable to enrolment or is already enrolled by the regulator into a role in the regulatory regime. An organization that enjoys high legitimacy with a regulator's target audiences presents an attractive target for a legitimacy-poor regulator to enroll in support of its own regulatory agenda. This actor is similar to an intermediary in the orchestration/RIT models insofar is it possesses capacities that the regulator lacks or that the intermediary can provide more effectively or efficiently (ibid.). In my account, the capacities the actor can provide must include legitimacy, though they can also include other resources as noted above. 
The legitimacy-rich actor does not necessarily play the role of an intermediary as defined in the orchestration/RIT models, namely acting in conjunction with a regulator to change the behaviour of the regulator's targets (ibid.). In my approach the actor can be enrolled into the position of intermediary, target, beneficiary or even regulator. In my case study, the ILO was enrolled as a regulator - a participant in ISO rule making. What makes the underdog strategy distinctive is that the capacity-rich actor is enrolled doubly. It is enrolled by the regulator to boost the regulator's legitimacy, and by the underdog to boost the underdog's effectiveness. I will call this actor the booster.

The relationship between the regulator and the booster follows the pattern of legitimation and enrolment I described earlier: the legitimacy-rich actor has capacities the regulator lacks, the regulator deploys legitimation strategies to enrol the legitimacy-rich actor into the desired relation, the legitimacy-rich actor responds with legitimation demands of its own, and the legitimacy-rich actor is (or is not) enrolled into the desired regulatory role and confers (or does not confer) legitimacy and possibly other regulatory capacities on the regulator.

The role of the underdog is more complicated. It takes advantage of the legitimation differential between the regulator and the booster. It relates to the regulator as a legitimacy granting or withholding audience and in this sense is positioned similarly toward the regulator as the booster is, except that the regulator lacks incentives to respond to its legitimation claims. So the underdog accentuates the regulator's legitimation deficit and the booster's corresponding surplus. It advocates the regulator's acquiescence to the booster's legitimation demands, and if this happens it exploits the regulator's enrolment of the booster to advance its own goals. It can do so proactively, as when labour experts actively invoked the ILO's special status to advance their interests. It can also do so passively, riding a wave of legitimacy conferred on the booster by other audiences. This was seen when labour rode the wave of support for the ILO built up by participants from all stakeholder categories and by the ILO itself.

The underdog enrols the booster and its regulatory capacities-especially its legitimacy with other audiences from whom the regulator seeks legitimation-as a force multiplier. This does not imply that the booster would not have got involved but for the underdog's efforts. It is possible that the booster would have involved itself for other reasons. My triadic model applies either way. The underdog enrols the booster not in the sense that it causes the booster to do something it would not otherwise have done, but in the sense that it takes advantage of the booster's capacities to advance its own agenda, and the booster allows this to happen. This is the sense in which the underdog enrols the booster. For this process to work, it appears that the goals of the underdog and the booster must be compatible, as in the orchestration model (Abbott et al. 2015b, 18-19) but not in the general RIT model (Abbott, Levi-Faur, and Snidal 2017, 19). In my case, organized labour could not have mobilized the ILO's legitimacy resources if their goals were incompatible.

In short, the case of organized labour, the ILO and ISO 26000 sheds light on the interactive dynamics of legitimation in transnational governance by suggesting a triadic strategy in which a marginalized actor advances its interests by accentuating and taking advantage of the relationship between a regulator with a self-perceived legitimation deficit and a potential booster with an abundance of legitimacy in the same regulatory space. 


\section{Endnotes}

1 The WGSR archive is available at http://www.iso.org/wgsr.

2 'Mirror committee' is the term for the committee that provides input to an ISO member body regarding positions its representatives should take in international negotiations.

${ }^{3}$ I say 'broadly' because they typically share the same values of free enterprise and market liberalization, and standardizers and service providers typically see themselves as serving the needs of industry. But their interests can conflict insofar as standardizers and service providers stand to benefit from increasing the number and complexity of standards whereas industry has incentives to limit them (Tamm Hallström and Boström 2010, 37; Wood 2012b).

${ }^{4} \mathrm{~A}$ brief methodological note is in order. I derived 137 distinct elements of ILSs in 28 subject areas from the ILO's official summary of ILSs (International Labour Office 2014) (excluding instruments adopted after 2010) and the version of the Tripartite Declaration of Principles Concerning Multinational Enterprises and Social Policy (ILO MNE Declaration) that was in force when ISO 26000 was published (International Labour Organization 2006). While these two sources do not embody all the details of the ILSs, they give an accurate picture of what the ILO considers the key features of ILSs and how they apply to business firms. I assessed the scope, specificity and rigour of ISO 26000, SA8000:2008 (Social Accountability International 2008), the BSCl Code of Conduct (Foreign Trade Association 2009) and the official guide to the UN Global Compact's labour principles (International Labour Organization 2008) against these 137 elements. 'Rigour' refers only to the ambition of the standard, not its degree of obligation, since ISO 26000 as a guidance document was precluded from using obligatory language.

${ }^{5}$ These were three of the best known and widest used cross-sectoral SR initiatives when ISO 26000 was being drafted. The United Nations Global Compact (UNGC) was and remains the world's highest-profile social responsibility initiative. It is a platform for making general commitments and sharing best practices. SA8000:2008 was a certification standard for corporate social accountability, focusing on labour practices. Like ISO 26000, it was produced by a purportedly multi-stakeholder process in which labour was vastly outnumbered. $\mathrm{BSCl}$ is a self-regulatory code of conduct produced by the leading European association of multinational businesses.

${ }^{6}$ For a comparison of ISO 26000's treatment of the concept of sphere of influence with that of the 2011 UN Guiding Principles on Business and Human Rights, see (Wood 2012a).

${ }^{7} \mathrm{OHS}$ is the term employed by ISO and most of its member bodies, whereas the ILO uses the term OSH (occupational safety and health). For consistency, I use the term OHS in this chapter.

8 Information about these events is drawn from published sources (e.g. Heras-Saizarbitoria, Ibarloza, and Díaz de Junguitu 2018) and from an interview with Emily Sims, Senior Specialist, Multinational Enterprises Development, International Labour Office, and ILO representative to the WGSR (20 May 2008).

${ }^{9}$ In the interest of full disclosure, I was retained by the ILO to advise it on effective participation in this ISO committee during parts of 2014 and 2015. 


\section{References}

Abbott, Kenneth W., Philipp Genschel, Duncan Snidal, and Bernhard Zangl, eds. 2015a. International Organizations as Orchestrators. Cambridge, UK: Cambridge University Press.

_-_. 2015b. "Orchestration: Global Governance through Intermediaries." In International Organizations as Orchestrators, edited by Kenneth W. Abbott, Philipp Genschel, Duncan Snidal, and Bernhard Zangl, 3-36. Cambride, UK: Cambridge University Press.

Abbott, Kenneth W., David Levi-Faur, and Duncan Snidal. 2017. "Theorizing Regulatory Intermediaries: The RIT Model." Annals of the American Academy of Political and Social Sciences 670 (1):14-35.

Abbott, Kenneth W, and Duncan Snidal. 2009. "Strengthening International Regulation Through Transnational New Governance: Overcoming the Orchestration Deficit." Vanderbilt Journal of Transnational Law 42:501-78.

Anonymous. 2005. "Summary Record of Meeting between ISO and ILO Concerning Guiding Principles for a Memorandum of Understanding (MoU) between ISO and ILO."

Bernstein, Steven, and Benjamin Cashore. 2007. "Can Non-State Global Governance Be Legitimate? An Analytical Framework." Regulation and Governance 1 (4):347-71.

Black, Julia. 2008. "Constructing and Contesting Legitimacy and Accountability in Polycentric Regulatory Regimes." Regulation and Governance 2 (2):137-64.

- - . 2009. "Legitimacy and the Competition for Regulatory Share." LSE Law, Society and Economy Working Paper 14/2009. London: LSE Law Department.

Buhmann, Karin. 2015. "Business and Human Rights: Understanding the UN Guiding Principles from the Perspective of Transnational Business Governance Interactions." Transnational Legal Theory 6 (2):399-434.

Callon, Michel. 1984. "Some Elements of a Sociology of Translation: Domestication of the Scallops and the Fishermen of St. Brieuc Bay." Sociological Review 32 (1):196-233.

Cashore, Benjamin, Graeme Auld, and Deanna Newsom. 2004. Governing through Markets: Forest Certification and the Emergence of Non-State Authority. New Haven: Yale University Press.

Cotterrell, Roger. 2016. "Transnational Legal Authority: A Socio-Legal Perspective." In Authority in Transnational Legal Theory: Theorising Across Disciplines, edited by Roger Cotterrell and Maksymilian Del Mar, 253-79. Cheltenham, UK; Northampton, MA: Edward Elgar.

Eberlein, Burkard, Kenneth W. Abbott, Julia Black, Errol Meidinger, and Stepan Wood. 2014. "Transnational Business Governance Interactions: Conceptualization and Framework for Analysis." Regulation and Governance 8 (1):1-21.

Foreign Trade Association. 2009. "BSCl Code of Conduct." Brussels: Foreign Trade Association.

Fox, Stephen. 2000. "Communities of Practice, Foucault and Actor-Network Theory." Journal of Management Studies 37 (6):853-67.

Fransen, Luc. 2012. "Multi-Stakeholder Governance and Voluntary Programme Interactions: Legitimation Politics in the Institutional Design of Corporate Social Responsibility." SocioEconomic Review 10 (1):163-92.

Giddens, Anthony. 1982. Profiles and Critiques in Social Theory. Berkeley and Los Angeles: University of California Press.

Gulbrandsen, Lars H. 2005. "Sustainable Forestry in Sweden: The Effect of Competition Among Private Certification Schemes." Journal of Environment and Development 14 (3):338-55. Gulbrandsen, Lars H. 2010. Transnational Environmental Governance: The Emergence and Effects 
of the Certification of Forests and Fisheries. Cheltenham, UK; Northampton, MA: Edward Elgar.

Heras-Saizarbitoria, Iñaki, Ander Ibarloza, and Alberto Díaz de Junguitu. 2018. "Conflicts Arising in the Generation Process of the ISO 45001 Standard." In ISO 9001, ISO 14001, and New Management Standards, edited by Iñaki Heras-Saizarbitoria, 177-91. Cham, Switzerland: Springer.

International Labour Office. 2001. Guidelines on Occupational Safety and Health Management Systems, ILO-OSH 2001. Geneva: International Labour Organization.

- - - 2014. Rules of the Game: A Brief Introduction to International Labour Standards. 3rd revised ed. Geneva: International Labour Organization.

International Labour Organization. 2006. "Tripartite Declaration of Principles Concerning Multinational Enterprises and Social Policy." Geneva: International Labour Organization.

- - - 2007. "Governing Body, 298th Session, Geneva, March 2007, Report of the DirectorGeneral, Fifth Supplementary Report: Collaboration between the ILO and ISO." Geneva.

- - - 2008. The Labour Principles of the United Nations Global Compact: A Guide for Business. Geneva: International Labour Organization.

- - . 2017a. "Review of the Implementation of ILO-ISO Agreements."

- - - 2017b. "Decision on the Tenth Item on the Agenda: Review of the Implementation of ILOISO Agreements." http://www.ilo.org/gb/decisions/GB331-decision/WCMS_592322/lang-en/index.htm.

International Organization for Standardization, and International Labour Organization. 2005. "Memorandum of Understanding between the International Labour Organization and the International Organization for Standardization in the Field of Social Responsibility."

- - - 2013. "Agreement between the International Labour Organization (ILO) and the International Organization for Standardization (ISO)."

International Organization of Employers. 2017. "Employers Concerned by ISO 45001: An Unbalanced and Impractical Standard for SMEs." October 3, 2017. https://www.ioeemp.org/policy-areas/occupational-safety-health/osh-news-details/article/employersconcerned-by-iso-45001-an-unbalanced-and-impractical-standard-for-smes/.

International Trade Union Confederation. 2010. "ITUC Comment on ISO 26000 FDIS." Brussels.

- - . 2017. "ITUC Statement Following Approval of the ISO Standard 45001 on Occupational Health and Safety Management Systems." https://www.ituc-csi.org/ituc-statement-followingapproval.

ISO (International Organization for Standardization). 1997. Friendship Among Equals: Recollections from ISO's First Fifty Years. Edited by Jack (compiler) Latimer. Geneva: International Organization for Standardization.

- - - 2002. "The Desirability and Feasibility of ISO Corporate Social Responsibility Standards." Geneva.

- - . 2004a. "New Work Item Proposal: ISO 26000 Guidance on Social Responsibility."

- - - 2004b. "Recommendations to the ISO Technical Management Board." Geneva: International Organization for Standardization.

- - . 2004c. "Working Report on Social Responsibility." Geneva.

- - - 2005. "Draft Minutes of the Second Meeting of ISO/TMB/WG Social Responsibility." Geneva.

- - - 2007. "Comments Received on ISO/WD 26000.3, Clause 6." Geneva. 
- - . 2008. "Comments Received on ISO/WD 26000.4.2." Geneva.

- - . 2010a. "Comments of the International Labour Office for Circulation with ISO/FDIS 26000." Geneva.

- - - 2010b. ISO 26000:2010, Guidance on Social Responsibility. 1st ed. Geneva: International Organization for Standardization.

- - - 2011. "Report and Recommendations to the ISO/TMB on Alternative Models of Standards Development Operations and Participation in ISO." Geneva.

- - - 2017. "The ISO Survey of Management System Standard Certifications 2016: Executive Summary." Geneva.

- - - 2018. "Annual Report 2017: Building for a Better Future." Geneva.

Justice, Dwight W. 2011. "Labour Practices." In Understanding ISO 26000: A Practical Approach to Social Responsibility, edited by Adrian Henriques, 21-31. London: British Standards Institution.

Latour, Bruno. 1984. "The Powers of Association." The Sociological Review 32:264-80.

Murphy, Craig N, and JoAnne Yates. 2009. The International Organization for Standardization (ISO): Global Governance through Voluntary Consensus. London and New York: Routledge.

Quack, Sigrid. 2016. "Expertise and Authority in Transnational Governance." In Authority in Transnational Legal Theory: Theorising Across Disciplines, edited by Roger Cotterrell and Maksymilian Del Mar, 361-86. Cheltenham, UK; Northampton, MA: Edward Elgar.

Schmiedeknecht, Maud. 2008. "ISO 26000: Reflecting the Process of a Multi-Stakeholder Dialogue-An Empirical Study." 29/2008. KleM Working Paper. Konstanz.

Social Accountability International. 2008. "SA8000: 2008 Social Accountability 8000." New York: Social Accountability International.

Suchman, Mark C. 1995. "Managing Legitimacy: Strategic and Institutional Approaches." Academy of Management Review 20 (3):571-610.

Szablowski, David. 2007. Transnational Law and Local Struggles: Mining, Communities and the World Bank. Oxford and Portland, Oregon: Hart.

Tamm Hallström, Kristina, and Magnus Boström. 2010. Transnational Multi-Stakeholder Standardization: Organizing Fragile Non-State Authority. Cheltenham, UK; Northampton, MA: Edward Elgar.

Webb, Kernaghan. 2015. "ISO 26000 Social Responsibility Standard as 'Proto Law' and a New Form of Global Custom: Positioning ISO 26000 in the Emerging Transnational Regulatory Rovernance Rule Instrument Architecture." Transnational Legal Theory 6 (2):466-500.

Weber, Max. 1978. Economy and Society: An Outline of Interpretive Sociology. Edited by Guenther Roth and Claus Wittich. Translated by Ephraim Fischoff. Berkeley: University of California Press.

Wood, Stepan. 2003. "Green Revolution or Greenwash? Voluntary Environmental Standards, Public Law, and Private Authority in Canada." In New Perspectives on the Public-Private Divide, edited by Law Commission of Canada, 123-65. Vancouver: UBC Press.

- - - 2005. "Three Questions About Corporate Codes: Problematizations, Authorizations and the Public/Private Divide." In Ethics Codes, Corporations and the Challenge of Globalization, edited by Wesley Cragg, 245-88. Cheltenham, UK; Northampton, MA: Edward Elgar.

- - - 2012a. "The Case for Leverage-Based Corporate Human Rights Responsibility." Business Ethics Quarterly 22 (1):63-98. http://www.jstor.org/stable/23223699.

- - . 2012b. "The International Organization for Standardization." In Business Regulation and 
Non-State Actors: Whose Standards? Whose Development?, edited by Darryl Reed, Peter Utting, and Ananya Mukherjee-Reed, 81-94. New York: Routledge.

Wood, Stepan, Kenneth W Abbott, Julia Black, Burkard Eberlein, and Errol Meidinger. 2015. "The Interactive Dynamics of Transnational Business Governance: A Challenge for Transnational Legal Theory." Transnational Legal Theory 6 (2):333-69.

https://doi.org/10.1080/20414005.2015.1092267. 